\title{
ON THE POISONS OF PLANT-LICE.*
}

\author{
By J. Dewitz,
}

Metz, Germany.

Although applied entomology has made enormous progress during recent years both in its scope and importance, we cannot deny that it has hitherto moved only in certain restricted paths and is therefore in danger of becoming one-sided, for the subject is taken up at present almost exclusively with a study of lifehistories, with parasites and the empirically ascertained methods of combatting injurious species. $\dagger$ Thus it has come about that up to the present time we know very little concerning the secretion of poisons by the sucking plant-parasites and the effects of these poisons on the plants. Most attention has been paid to this question by those who have investigated the origin of plant galls. Hence it may be of interest to record some investigations which I have made on the poisons of plant-lice.

In addition to the bacterial poisons we may distinguish those of certain animals (snakes, scorpions, bees, etc.) which are characterized only by certain pecularities such as the lack of an incubation period. These animal poisons have been best studied in snakes. But there are also some researches on the poisons of arthropods (spiders, myriopods, insects). The attempt, however, has hardly been made to investigate carefully the poisons produced by the plant parasites, especially by the plant lice.

The toxins of bacteria and fungi and the animal poisons have the property of hæmolyzing, or dissolving the red pigment (hæmoglobin) of the blood corpuscles of mammals, and we therefore speak of the hæmolysis of the toxins and of animal poisons. Under their influence a dilution of red blood corpuscles in physiological salt solution takes on a clear, transparent, red color like that of lac. The poison of a particular species, however, will hæmolyze only the red blood-corpuscles of particular species of mammals, namely, those which are susceptible to the poison in question; the red blood-corpuscles of other

*Translation by W. M. Wheeler.

$\dagger J$. Dewitz, Die Physiologie in der Schadlingsforschung. Trans. Second Ent. Congress 1912 pp. 234-244; The Bearing of Physiology on Economic Entomology. Bull. Ent. Research, Vol. 3, 1912, pp. 343-354. 
mammals being only slightly or not at all affected. Thus the red blood corpuscles of the rabbit and rat are very sensitive to the poison of the house-spider ("Kreuzspinne," Araneus diadematus Clerck) and undergo complete hæmolysis, those of the mouse, man and goose are less sensitive and in the case of the guinea pig, horse, sheep and dog even great quantities of the poison do not produce hæmolysis.* It is this peculiar property of the poisons, known as hæmolysis, that I have begun to investigate in plant lice. My work has been carried on with an unidentified species of plant-louse living on Pelargonium, the hæmolytic experiments being performed in the traditional manner. $\dagger$ Among the animals investigated the red blood corpuscles of the ox were found to be sensitive to the poisons of the plant-louse.

The plant lice were triturated in a certain quantity of physiological salt solution ( 0.8 per cent) or in a mixture of glycerine and physiological salt-solution and placed for 24 hours in the ice-chest. Then, after filtration, the extract was used. On the other hand, I obtained a solution of defibrinated ox blood, drawn off under aseptic conditions, of 5 per cent solution. This was centrifuged, the liquid being thrice replaced with physiological salt solution, which finally gave a 5 per cent dilution of red-blood corpuscles. This dilution was mixed in variable quantities with plant-louse extract in small tubes, such as are used for serum investigations. Then the tubes were warmed in the thermostat for two hours at $37^{\circ} \mathrm{C}$. and placed over night in the ice-chest to obtain the sedimentation of such blood-corpuscles as were not dissolved. At the same time control experiments were carried on in such a manner that the control tubes were heated and placed in the ice-chest together with the tubes containing the extract. In these control experiments the plant louse extract was replaced by a corresponding amount of the physiological salt-solution or of a mixture of physiological salt-solution and glycerine.

It was found that the warm dilutions of the extract hæmolyze the blood-corpuscles of the ox and that this "hæmolysis"

*Hans Sachs, Zur Kenntnis des Kreuzspinnengiftes. Beitr. Chem. Physiol. u. Pathol. (Hofmeister) Bd. 2, 1902, pp. 125-133.

$\dagger$ Unfortunately, I am unable at the moment to give the scientific name of this plant-louse. 
takes place even at ordinary temperatures with the undiluted extract, as shown in the following example:

An extract was manufactured by triturating 0.5 gr. of plant-lice in $5 \mathrm{ccm}$. of a mixture of physiological salt-solution and glycerine in equal parts. In the dilutions of the extract used $1 \mathrm{~cm}$. of physiological salt-solution contained the following amounts of extract:

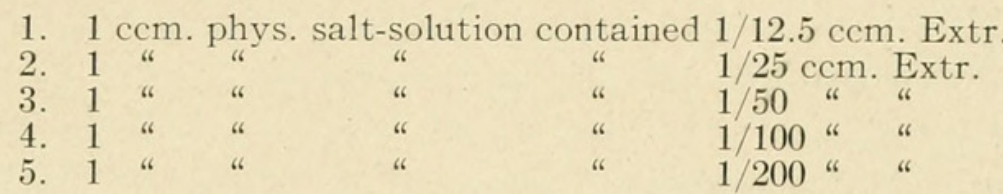

$1 \mathrm{ccm}$. of the diluted extract was mixed with $1 \mathrm{ccm}$. of the 5 per cent blood dilution. Nos. 1,2 and 3 gave complete hæmolysis. In No. 4 a small portion of the blood-corpuscles remained undissolved and in No. 5 the hæmolysis was incomplete. In the control tubes no hæmolysis occurred.

From this experiment and from another performed with the same sample of extract, which gave the same results, it is possible to make the following computations concerning the hæmolytic effect of plant-louse poison on the red blood corpuscles of the ox.

In $5 \mathrm{ccm}$. of extract there were $0.5 \mathrm{gr}$. of plant-louse matter or $0.1 \mathrm{gr}$. to $1 \mathrm{ccm}$. of extract. In $1 / 200 \mathrm{ccm}$. of extract there was therefore $0.0005 \mathrm{gr}$. of plant-louse matter. This 0.0005 gr. brought about a partial solution of the red corpuscles in $1 \mathrm{ccm}$. of a 5 per cent dilution of blood or the solution of the red-corpuscles of $0.05 \mathrm{ccm}$. of the undiluted blood of the ox. A complete solution of the red-blood corpuscles of $0.05 \mathrm{ccm}$. of the undiluted blood of the ox did not, however, take place till $1 / 50 \mathrm{ccm}$. of the extract or $0.002 \mathrm{gr}$. of plant-louse matter was used. In other words, 1 gr. of plant-louse matter will completely dissolve the red-blood corpuscles of $25 \mathrm{ccm}$. of undiluted blood or $40 \mathrm{gr}$. will dissolve a litre of blood.

The hæmolytic power of "aphidolysin," as we may call the substance, is therefore weaker than the poison of the housespider ("arachnolysin"), * since 0.000028 gr. of this substance completely dissolves the red blood corpuscles of $0.05 \mathrm{ccm}$. of the undiluted blood of the rabbit (i. e. $1.4 \mathrm{gr}$. dissolves

*Hans Sachs loc. cit. 
2.5 litres or 0.56 gr. will dissolve 1 litre). But we may say that perhaps by further search mammalian blood corpuscles. may be found, which are more sensitive to the poison of the plant-louse I have used than the blood of the ox.

Another point also deserves emphasis. Although a hæmolytic poison is found in the organism of the plant-louse, we are unable at present to name the part of the body in which it occurs. This is also true of the hæmolytic experiments which have been performed on the house-spider, since in this case also the whole spider was triturated. The case of the hæmolytic experiments on the poison of honey bees, however, is different, since the sting together with the poison sac was extracted, and operations were therefore carried out on the poison organ alone.*

*Conf. J. Morgenroth u. U. Carpi, Ueber ein Toxolecithid des Bienengiftes. Ber1. Klinisch. Wochenschrift. Jahrg. 43, 1906, pp. 1424-1425. 


\section{$2 \mathrm{BHL}$ Biodiversity Heritage Library}

Dewitz, J . 1915. "On the Poisons of Plant-Lice." Annals of the Entomological Society of America 8, 343-346. https://doi.org/10.1093/aesa/8.4.343.

View This Item Online: https://www.biodiversitylibrary.org/item/43631

DOI: https://doi.org/10.1093/aesa/8.4.343

Permalink: https://www.biodiversitylibrary.org/partpdf/193777

\section{Holding Institution}

Smithsonian Libraries

\section{Sponsored by}

Smithsonian

\section{Copyright \& Reuse}

Copyright Status: NOT_IN_COPYRIGHT

This document was created from content at the Biodiversity Heritage Library, the world's largest open access digital library for biodiversity literature and archives. Visit BHL at https://www.biodiversitylibrary.org. 